\title{
Aerosol effects on the development of cumulus clouds over the Tibetan Plateau
}

\author{
Xu Zhou ${ }^{1,5}$, Naifang Bei ${ }^{2}$, Hongli Liu ${ }^{3}$, Junji Cao ${ }^{1}$, Li Xing ${ }^{1}$, Wenfang Lei ${ }^{4}$, Luisa T. Molina ${ }^{4}$, and Guohui $\mathbf{L i}^{1}$ \\ ${ }^{1}$ Key Lab of Aerosol Chemistry and Physics, SKLLQG, Institute of Earth Environment, Chinese Academy of Sciences, \\ Xi'an, China \\ ${ }^{2}$ School of Human Settlements and Civil Engineering, Xi'an Jiaotong University, Xi' an, Shaanxi, China \\ ${ }^{3}$ State Key Laboratory of Severe Weather, Chinese Academy of Meteorological Sciences, Beijing, China \\ ${ }^{4}$ Molina Center for Energy and the Environment, La Jolla, CA, USA \\ ${ }^{5}$ University of Chinese Academy of Science, Beijing, China
}

Correspondence to: Guohui Li (ligh@ieecas.cn)

Received: 16 February 2017 - Discussion started: 23 February 2017

Revised: 7 May 2017 - Accepted: 9 May 2017 - Published: 20 June 2017

\begin{abstract}
The aerosol-cloud interaction over the Tibetan Plateau has been investigated using a cloud-resolving weather research and forecasting model with a two-moment bulk microphysical scheme including aerosol effects on cloud condensation nuclei and ice nuclei. Two types of cumulus clouds with a similar convective available potential energy, occurring over the Tibetan Plateau (Cu-TP) and North China Plain (Cu-NCP) in August 2014, are simulated to explore the response of convective clouds to aerosols. A set of aerosol profiles is used in the simulations, with the surface aerosol number concentration varying from 20 to $9000 \mathrm{~cm}^{-3}$ and the sulfate mass concentration varying from 0.02 to $9.0 \mu \mathrm{g} \mathrm{cm}^{-3}$. Increasing aerosol concentrations generally enhances the cloud core updraft and maximum updraft, intensifying convections in $\mathrm{Cu}-\mathrm{TP}$ and $\mathrm{Cu}-\mathrm{NCP}$. However, the core updraft is much stronger in $\mathrm{Cu}-\mathrm{TP}$ than $\mathrm{Cu}-\mathrm{NCP}$, because of the early occurrence of the glaciation process in $\mathrm{Cu}$-TP that is triggered at an elevation above $4000 \mathrm{~m}$. The precipitation increases steadily with aerosol concentrations in $\mathrm{Cu}-\mathrm{NCP}$, caused by the suppression of the warm rain but occurrence of efficient mix-phased precipitation due to the reduced cloud droplet size. The precipitation in $\mathrm{Cu}-\mathrm{TP}$ also increases with aerosol concentrations, but the precipitation enhancement is not substantial compared to that in $\mathrm{Cu}-\mathrm{NCP}$ with high aerosol concentrations. The aerosol-induced intensification of convections in $\mathrm{Cu}$-TP not only facilitates the precipitation but also transports more ice-phase hydrometeors into the upper troposphere to decrease the precipitation efficiency. Consid-
\end{abstract}

ering the very clean atmosphere over the Tibetan Plateau, elevated aerosol concentrations can remarkably enhance convections due to its specific topography, which not only warms the middle troposphere to influence the Asian summer monsoon but also delivers hydrometeors into the upper troposphere to allow more water vapor to travel into the lower stratosphere.

\section{Introduction}

Atmospheric aerosols, formed naturally and anthropogenically, influence the radiative energy budget of the Earthatmosphere system in many ways. They scatter or absorb a fraction of the incoming solar radiation to cool or warm the atmosphere, decreasing surface temperature and altering atmospheric stability (e.g., Jacobson, 2002; Wang et al., 2013). They also serve as cloud condensation nuclei (CCN) and ice nuclei (IN), modifying optical properties and lifetime of clouds (e.g., Penner et al., 2001; Zhang et al., 2007). The aerosol indirect effect, generally referred to as the aerosol impact on cloud reflective properties and lifetime (Twomey, 1977; Houghton, 2001), has constituted one of the largest uncertainties in climate prediction (IPCC, 2013). In addition, the aerosol effects on precipitation have been regarded as an important but poorly understood process that could have major implications to climate and water supplies (Levin and Cotton, 2007; Wang et al., 2014a, b). 
For a given amount of condensable water vapor, elevated aerosol concentrations increase the number of cloud droplets and reduce their sizes, enhancing not only the reflective properties but also the lifetime of clouds through suppressing warm-rain processes (Twomey, 1977; Albrecht, 1989). Accumulative observational and modeling evidence has shown that reduced cloud droplet size, due to increasing $\mathrm{CCN}$, inhibits collision and coalescence processes, suppressing warm rain and delaying the onset of precipitation. Therefore, more droplets are further allowed to be transported above the $0{ }^{\circ} \mathrm{C}$ isotherm, triggering the efficient mixed-phase process to release more latent heat and intensify the convection (e.g., Rosenfeld and Lensky, 1998; Rosenfeld and Woodley, 2000; Kaufman and Nakajima, 1993; Andreae et al., 2004; Kaufman et al., 2005; Fan et al., 2007a; Khain et al., 2008; Koren et al., 2010; Li et al., 2013; Loftus and Cotton, 2014). However, recent studies have shown that an optimal aerosol loading exists to invigorate convection (Rosenfeld et al., 2008; Koren et al., 2014; Dagan et al., 2015). Additionally, the aerosol impacts on cloud developments are also proposed to be dependent on the environmental conditions, such as relative humidity and vertical wind shear (Van Den Heever et al., 2007; Lee et al., 2008; Fan et al., 2009, 2016; Tao et al., 2012).

The observational and model-derived evidence on how aerosols influence rainfall remains elusive due to the complexity of cloud processes, which are determined by intricate thermodynamic, dynamical, and microphysical processes and their interactions (Levin and Cotton, 2007; McComiskey and Feingold, 2012; Lin et al., 2016). Observations have demonstrated that the aerosol effect on precipitation depends on both the type of aerosols and precipitating environments. Rainfall reduction has been observed in polluted industrial and urban regions in shallow clouds or clouds with the top temperature exceeding $-10^{\circ} \mathrm{C}$ (e.g., Rosenfeld, 2000; Ramanathan et al., 2001; Andreae et al., 2004; Yang et al., 2013). However, documented rainfall increase has also been observed around heavily polluted coastal areas or over oceans influenced by anthropogenic aerosols (e.g., Cerveny and Balling Jr., 1998; Shepherd and Burian, 2003; Zhang et al., 2007; Li et al., 2008b; Koren et al., 2012, 2014). Model results tend to support the argument that increasing aerosol concentrations enhances precipitation under a moist, unstable atmosphere (e.g., Khain et al., 2005; Fan et al., 2007b; Li et al., 2008a, 2009; Wang et al., 2011; Fan et al., 2013).

The Tibetan Plateau (TP), located in central eastern Eurasia and with an average elevation of more than $4000 \mathrm{~m}$, significantly affects the formation and variability of the Asian summer monsoon through mechanical and thermal dynamical effects (Wu et al., 2007). Due to its strong surface heating, the cumulus clouds are active over the TP and can be organized to form convective systems, contributing substantially to the precipitation over TP and adjacent areas. The TP is surrounded by several important natural and anthropogenic aerosol sources, and the in situ and satellite mea- surements have shown that anthropogenic aerosols and dust have been lofted to the TP, directly influencing the regional climate (Engling et al., 2011). Soot aerosols deposited on the TP glaciers have been confirmed to contribute significantly to observed glacier retreat (Xu et al., 2009). Absorbing aerosols over the TP have been proposed to directly affect monsoon rainfall through the elevated-heat-pump mechanism (Lau et al., 2008; D'Errico et al., 2015; Li et al., 2016).

However, to date few studies have been performed to investigate the aerosol indirect effect or the aerosol-cloud interaction over the TP. In the present study, we report an investigation of the aerosol effect on the cumulus cloud development and precipitation over the TP. Two types of cumulus clouds occurring over the TP and the North China Plain (NCP) are simulated using a cloud-resolving weather research and forecasting (CR-WRF) model for comparisons. The model configuration is described in Sect. 2. The results and discussions are presented in Sect. 3, and summary and conclusions are given in Sect. 4.

\section{Models and design of numerical experiments}

\subsection{Model configuration}

A CR-WRF model (Skamarock, 2004) is used in the study to simulate cumulus clouds. A two-moment bulk microphysical scheme developed by $\mathrm{Li}$ et al. (2008a) is utilized to account for the aerosol-cloud interactions in the simulations. The mass mixing ratio and number concentration of five hydrometeors are predicted in the bulk microphysical scheme, including cloud water, rain water, ice crystal, snow flake, and graupel. The gamma function is used to represent the size distribution of the five hydrometeors. Detailed information is provided in Li et al. (2008a).

In order to consider the aerosol activation to $\mathrm{CCN}$ and IN, the Community Multiscale Air Quality (CMAQ)/Model3 aerosol module (Binkowski and Roselle, 2003) is implemented into the CR-WRF model. Aerosols are simulated in the CMAQ using a modal approach assuming that particles are represented by three superimposed lognormal size distributions. The aerosol species - including sulfate, nitrate, ammonium, organic and black carbon, and other unidentified species (dust-like) - are predicted in the module.

For the CCN nucleation, the critical radius of dry aerosols is calculated from the $k$-Köhler theory developed by Petters and Kreidenweis $(2007,2008,2013)$ using water supersaturation predicted by the CR-WRF model (Rogers and Yau, 1989; Pruppacher and Klett, 1997). If the activated CCN radius is less than $0.03 \mu \mathrm{m}$, the mass of water condensation on $\mathrm{CCN}$ is calculated under the equilibrium assumption; otherwise, the mass of water condensing on $\mathrm{CCN}$ is calculated by $m_{\mathrm{w}}=K \frac{4}{3} \pi r_{\mathrm{a}}^{3} \rho_{\mathrm{w}}$ at zero supersaturation, where $3<K<8$ (Khain, 2000). Additionally, a novel, flexible approach proposed by Philips et al. $(2008,2013)$ has been used to param- 

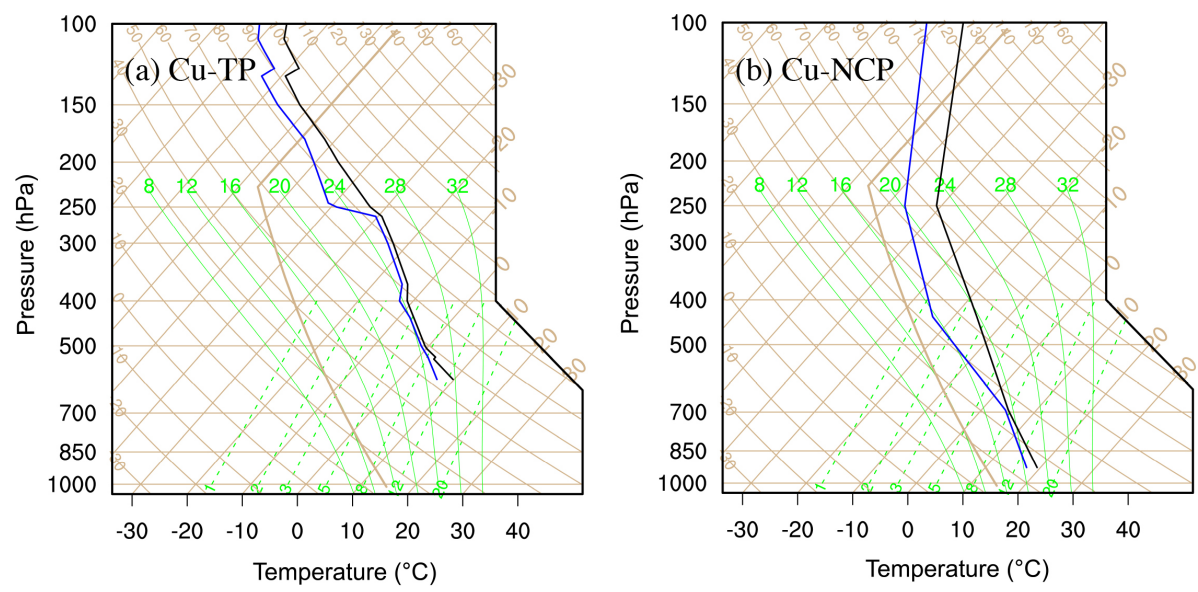

Figure 1. Atmospheric sounding (a) over the Tibetan Plateau $\left(87.08^{\circ} \mathrm{E}, 28.63^{\circ} \mathrm{N}, 4302 \mathrm{~m}\right.$ a.s.1.) at 08:00 UTC on 12 August 2014 and (b) over North China Plain $\left(114.35^{\circ} \mathrm{E}, 37.17^{\circ} \mathrm{N}, 181 \mathrm{~m}\right.$ a.s.1.) at 08:00 UTC on 24 August 2014. The black line corresponds to the temperature, and the blue line represents the dew point temperature.

eterize the ice heterogeneous nucleation within clouds. The method has empirically derived dependencies on the chemistry and surface area of multiple species of IN aerosols, mainly including dust and black and organic carbon aerosols. Three kinds of ice nucleation mechanisms are considered in the method: contact, immersion, and condensation freezing.

\subsection{Design of numerical experiments and statistical method in data analysis}

The spatial resolution used in the cloud simulations is $1 \mathrm{~km}$ in the horizontal direction and about $250 \mathrm{~m}$ in the vertical direction. The model domain of $200 \times 200 \times 80$ grid boxes along the $x, y$, and $z$ directions, respectively, has been used to provide $200 \mathrm{~km} \times 200 \mathrm{~km}$ horizontal and $20 \mathrm{~km}$ vertical coverage in this study. The initial and boundary conditions of water vapor are from the sounding data. The simulations use the open boundary conditions under which variables of all horizontal gradients are zero at the lateral boundary.

Two types of cumulus clouds are simulated using the CRWRF model. The cumulus cloud over the TP (hereafter referred to as $\mathrm{Cu}-\mathrm{TP}$ ) is initialized using the sounding data $\left(87.08^{\circ} \mathrm{E}, 28.63^{\circ} \mathrm{N}, 4302 \mathrm{~m}\right.$ a.s.1.) at 08:00 UTC on $24 \mathrm{Au}-$ gust 2014 (Fig. 1a). The cumulus cloud over the NCP (hereafter referred to as $\mathrm{Cu}-\mathrm{NCP}$ ) is initialized using the sounding data $\left(114.35^{\circ} \mathrm{E}, 37.17^{\circ} \mathrm{N}, 181 \mathrm{~m}\right.$ a.s.l.) at 08:00 UTC on 12 August 2014 (Fig. 1b). The selected sounding profiles over the TP and NCP reveal a moderate instability in the atmosphere, with similar convective available potential energy (CAPE) for comparison, i.e., $675 \mathrm{~J} \mathrm{~kg}^{-1}$ for $\mathrm{Cu}-\mathrm{TP}$ and $651 \mathrm{~J} \mathrm{~kg}^{-1}$ for $\mathrm{Cu}-\mathrm{NCP}$. Although $\mathrm{Cu}-\mathrm{TP}$ and $\mathrm{Cu}-\mathrm{NCP}$ have a similar CAPE, the remarkable difference of the initialization elevation between $\mathrm{Cu}-\mathrm{TP}$ and $\mathrm{Cu}-\mathrm{NCP}$ causes their distinct development processes. The $0^{\circ} \mathrm{C}$ isotherm is generally at a level of around $5 \mathrm{~km}$ a.s.l. in the summer. Therefore, when an air parcel perturbed in the boundary layer ascends to form a cloud, the rising distance to the $0^{\circ} \mathrm{C}$ isotherm is around $1 \mathrm{~km}$ over the TP and about $4 \mathrm{~km}$ over the NCP. Therefore, the occurrence of the efficient mixed-phase process is much earlier for the cumulus cloud over the TP than the NCP, which substantially advances the development of the cloud over the TP.

The cumulus development is triggered by a warm bubble $15 \mathrm{~km}$ wide and a maximum temperature anomaly of $4{ }^{\circ} \mathrm{C}$ at the height of $1.5 \mathrm{~km}$ a.g.1. (Li et al., 2008a), and the integration time is $2 \mathrm{~h}$. Observed aerosol concentrations over the TP exhibit a large variation during the monsoon season; i.e., the observed sulfate concentrations range from $0.1 \mu \mathrm{g} \mathrm{m}{ }^{-3}$ to several micrograms per square meter (Decesari et al., 2010). Therefore, a set of 28 initial aerosol size distributions with the aerosol number concentration ranging from 20 to $9000 \mathrm{~cm}^{-3}$ and the sulfate mass concentration ranging from 0.02 to $9.0 \mu \mathrm{g} \mathrm{cm}^{-3}$ at the surface level is used. Other aerosol species are scaled using the measurement at the Nepal Climate Observatory - Pyramid (NCO-P) (Decesari et al., 2010). These aerosol distributions are designated for environments ranging from very clean background air mass to polluted urban plumes over the TP and NCP. Although the observed organic aerosol dominates the aerosol composition at NCO-P (Decesari et al., 2010), considering the large uncertainties in the hygroscopicity of organic aerosols, the hygroscopicity parameter for the secondary organic aerosol is set to 0.05 in the study (Petters and Kreidenweis, 2007, 2008). Hence, sulfate aerosols (or inorganic aerosols) still play a dominant role in the $\mathrm{CCN}$ activation. The aerosol concentration is assumed to decrease exponentially with height in the model simulations ( $\mathrm{Li}$ et al., 2008a).

We have adopted several assumptions and simplifications for the processes associated with aerosols. In the simulations, only the accumulation mode of aerosols is used for the CCN and IN activation, and the aerosol spatial distributions are de- 
termined by the initial and boundary conditions, without consideration of chemistry, emissions, and release from cloud droplet evaporation or ice crystal sublimation. The sulfate, nitrate, ammonium, organic and black carbon, and dust-like aerosols in the accumulation mode are included to consider the aerosol CCN and IN effects. Therefore, the surface-level aerosol number concentration $\left(\left[N_{\mathrm{a}}\right]\right)$ is used to represent all types of aerosols, and the CCN concentration at a certain supersaturation (SS) is not used in the study. It is worth noting that the simple aerosol assumption is liable to cause rather large uncertainties in the aerosol activation to $\mathrm{CCN}$ and IN. Aerosol chemistry in clouds plays a considerable role in the aerosol nucleation and growth. Direct emissions from anthropogenic sources contribute substantially to the CCN and IN, even over the TP with increasing human activities. Furthermore, mineral dust from the natural source frequently dominates the TP throughout the year. Therefore, future studies need to be conducted to include all the aerosol modes, chemistry, and emissions.

In order to evaluate the overall response of simulated cumulus clouds to changes in aerosol concentrations, the population mean ( $p$ mean) of a given variable over all qualified grid points and for a given integration interval is used in the study (Wang, 2005), defined as

$$
\bar{C}^{\mathrm{p}}=\frac{1}{\sum_{t=T_{1}}^{T_{2}} N(t)} \sum_{t=T_{1}}^{T_{2}} \sum_{n>n_{\min }}^{q>q_{\min }} c(x, y, t),
$$

where $c$ represents a given quantity. The calculation only applies to the grid points where both the mass concentration $q$ and number concentration $n$ of a hydrometeor or the summation of several hydrometeors exceed the given minima. The total number of the grid points at a given output time step $t$ is represented by $N(t) . T_{1}$ and $T_{2}$ are the start and end output time steps, respectively.

\section{Results and discussions}

\subsection{Response of cloud properties to changes in aerosol concentrations}

Figure 2a depicts the dependence of the $p$ mean of the cloud droplet number concentration (CDNC) on the $\left[N_{\mathrm{a}}\right]$. Increasing $\left[N_{\mathrm{a}}\right]$ provides more $\mathrm{CCN}$ to activate, and, although more activated droplets compete for the available water vapor, the water vapor condensation efficiency is enhanced due to the increased bulk droplet surface area, accelerating the latent heat release and the updraft to provide more supersaturated water vapor. Therefore, the increasing $\mathrm{CDNC}$ is very consistent with increasing $\left[N_{\mathrm{a}}\right]$ in $\mathrm{Cu}-\mathrm{TP}$ and $\mathrm{Cu}-\mathrm{NCP}$, in good agreement with previous studies (e.g., Fan et al., 2007a, b; Li et al., 2008a). When the $\left[N_{\mathrm{a}}\right]$ increases from about 20 to $9000 \mathrm{~cm}^{-3}$, the $p$ mean of the CDNC increases from 0.56 to
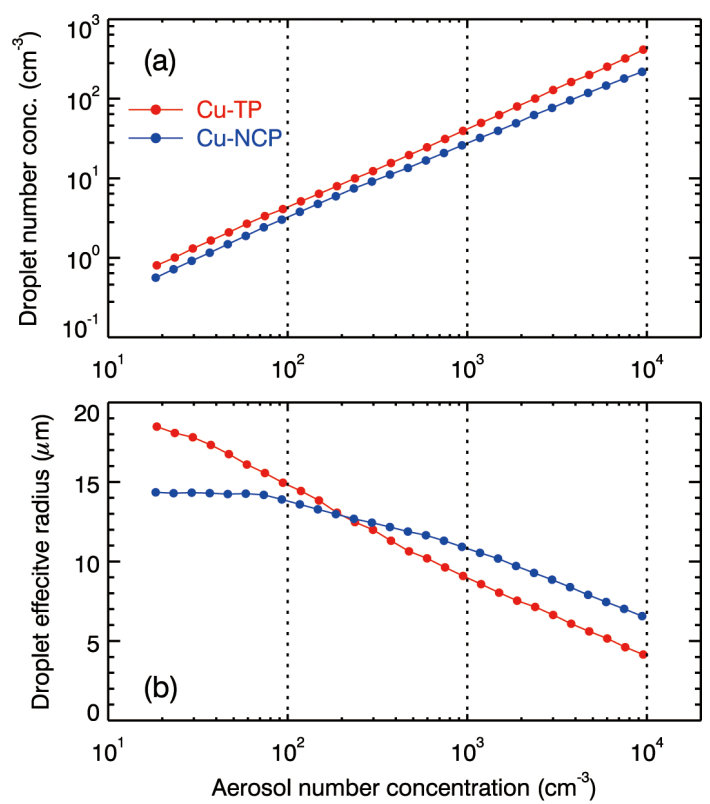

Figure 2. Modeled $p$ mean of (a) cloud droplet number concentration and (b) effective radius as a function of the initial $\left[N_{\mathrm{a}}\right]$ in $\mathrm{Cu}-\mathrm{TP}$ and $\mathrm{Cu}-\mathrm{NCP}$.
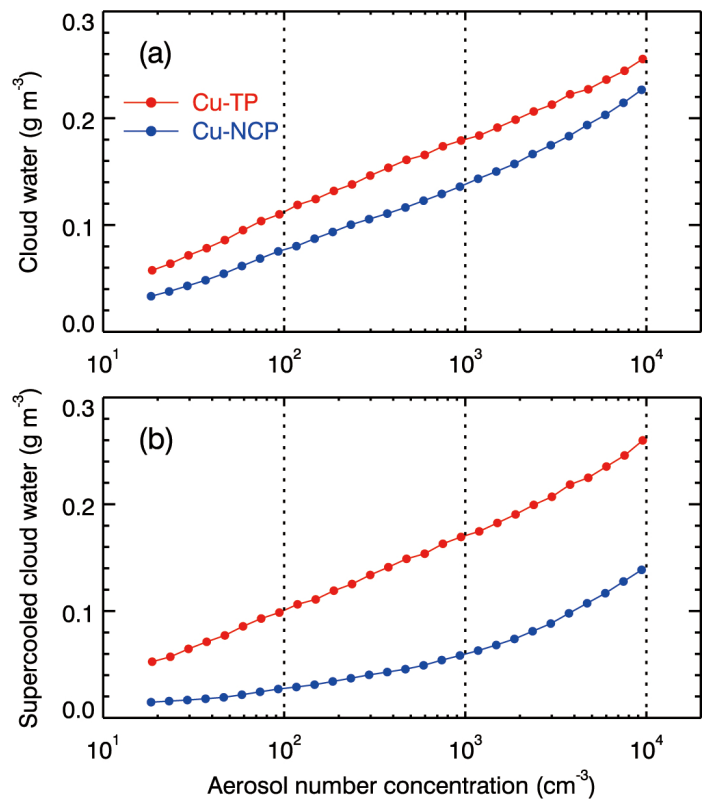

Figure 3. Modeled $p$ mean of (a) cloud water mass concentration and (b) supercooled cloud water mass concentration as a function of the initial $\left[N_{\mathrm{a}}\right]$ in $\mathrm{Cu}-\mathrm{TP}$ and $\mathrm{Cu}-\mathrm{NCP}$ in $\mathrm{Cu}-\mathrm{TP}$ and $\mathrm{Cu}-\mathrm{NCP}$.

$218 \mathrm{~cm}^{-3}$ for $\mathrm{Cu}-\mathrm{NCP}$. However, more aerosols are activated in $\mathrm{Cu}-\mathrm{TP}$ compared to $\mathrm{Cu}-\mathrm{NCP}$, and the $p$ mean of the $\mathrm{CDNC}$ increases from 0.80 to $415 \mathrm{~cm}^{-3}$ for $\mathrm{Cu}-\mathrm{TP}$. Although the $\mathrm{CAPE}$ is similar for $\mathrm{Cu}-\mathrm{TP}$ and $\mathrm{Cu}-\mathrm{NCP}$, the $p$ mean of $\mathrm{CDNC}$ in $\mathrm{Cu}-\mathrm{TP}$ is higher than that in $\mathrm{Cu}-\mathrm{NCP}$ with the same $\left[N_{\mathrm{a}}\right]$. 
With the $\left[N_{\mathrm{a}}\right]$ increasing from 20 to $9000 \mathrm{~cm}^{-3}$, the effective radius of cloud droplet $\left(R_{\text {eff }}\right)$ in $\mathrm{Cu}-\mathrm{TP}$ is reduced from about 18.5 to $4.1 \mu \mathrm{m}$, and the $R_{\text {eff }}$ in $\mathrm{Cu}-\mathrm{NCP}$ is also consistently reduced from 14.3 to $6.6 \mu \mathrm{m}$ (Fig. $2 \mathrm{~b}$ ). Interestingly, when the $\left[N_{\mathrm{a}}\right]$ is less than about $240 \mathrm{~cm}^{-3}$, the $R_{\text {eff }}$ in $\mathrm{Cu}$-TP is larger than that in $\mathrm{Cu}-\mathrm{NCP}$ with the same $\left[N_{\mathrm{a}}\right]$, although the $\mathrm{CDNC}$ in $\mathrm{Cu}-\mathrm{TP}$ is higher than that in $\mathrm{Cu}-\mathrm{NCP}$, showing more cloud water condensed in $\mathrm{Cu}$-TP. Figure $3 \mathrm{a}$ presents the dependence of the cloud water content (CWC) on the $\left[N_{\mathrm{a}}\right]$ in $\mathrm{Cu}-\mathrm{TP}$ and $\mathrm{Cu}-\mathrm{NCP}$, showing that the $\mathrm{CWC}$ increases with increasing $\left[N_{\mathrm{a}}\right]$. This positive relationship is caused by the combined effects of the increase in CDNC and the decrease in $R_{\text {eff }}$, which inhibit the collision/coalescence of cloud droplets and also enhance the water vapor condensation efficiency and the updraft to generate more available condensable water vapor. The $\mathrm{CWC}$ in $\mathrm{Cu}-\mathrm{TP}$ is higher than that in $\mathrm{Cu}-\mathrm{NCP}$ for the same $\left[N_{\mathrm{a}}\right]$, due to higher CDNC and likely stronger updrafts in $\mathrm{Cu}-\mathrm{TP}$. The $\mathrm{Cu}-\mathrm{TP}$ is triggered at an elevation of more than $4000 \mathrm{~m}$ a.s.l. Therefore, considering that the $0{ }^{\circ} \mathrm{C}$ isotherm is at a level of around $5000 \mathrm{~m}$ a.s.l., the cloud water formed in the cumulus tends to be transported above the $0^{\circ} \mathrm{C}$ isotherm to become supercooled, initiating the efficient mixed-phase process to release more latent heat and enhance the updraft. Therefore, there exists more supercooled cloud water in $\mathrm{Cu}-\mathrm{TP}$ than $\mathrm{Cu}-\mathrm{NCP}$ when $\left[N_{\mathrm{a}}\right]$ is the same (Fig. 3b).

Figure 4 provides the vertical profiles of the hydrometeors mass concentrations (summed over the horizontal domain and then averaged during the simulation period) under three aerosol scenarios: a very low $\left[N_{\mathrm{a}}\right]$ of $90 \mathrm{~cm}^{-3}$, a low $\left[N_{\mathrm{a}}\right]$ of $900 \mathrm{~cm}^{-3}$, and a high $\left[N_{\mathrm{a}}\right]$ of $9000 \mathrm{~cm}^{-3}$, corresponding to the background, clean, and polluted atmosphere, respectively. In $\mathrm{Cu}-\mathrm{TP}$ and $\mathrm{Cu}-\mathrm{NCP}$, the $\mathrm{CWC}$ achieves the highest level under the high $\left[N_{\mathrm{a}}\right]$ case and the lowest under the very low $\left[N_{\mathrm{a}}\right]$ case (Fig. $4 \mathrm{a}$ and b). A higher $\left[N_{\mathrm{a}}\right]$ enhances CDNC and reduces $R_{\text {eff }}$, suppressing the conversion from cloud water to rain water and sustaining more CWC in the cloud. In Table 1, the initial formation time of rain water is delayed with the $\left[N_{\mathrm{a}}\right]$ increase in $\mathrm{Cu}-\mathrm{TP}$ and $\mathrm{Cu}-\mathrm{NCP}$. The height of the maximum CWC slightly increases from the very low to high- $\left[N_{\mathrm{a}}\right]$ conditions in $\mathrm{Cu}-\mathrm{TP}$ and $\mathrm{Cu}-\mathrm{NCP}$, but the maximum $\mathrm{CWC}$ occurs at 6-8 km a.s.1. in $\mathrm{Cu}-\mathrm{TP}$ and 2$4 \mathrm{~km}$ a.s.l. in $\mathrm{Cu}-\mathrm{NCP}$. Therefore, for $\mathrm{Cu}-\mathrm{TP}$, most of cloud droplets are above the $0{ }^{\circ} \mathrm{C}$ isotherm (about $5 \mathrm{~km}$ a.s.l.) and supercooled.

The ice particles (ice + snow) generally reach the highest level in the high $\left[N_{\mathrm{a}}\right]$ and lowest in the very low $\left[N_{\mathrm{a}}\right]$, which is consistent with those of the CWC in $\mathrm{Cu}-\mathrm{TP}$ and $\mathrm{Cu}-\mathrm{NCP}$ (Fig. 4e and f). In the present study, the homogeneous freezing and rime-splintering mechanisms (DeMott et al., 1994; Hallett and Mossop, 1974) are included for the ice nucleation. In addition, the heterogeneous ice nucleation - including the contact, immersion, and condensation freezing - is all parameterized using the method proposed by Philips et al. $(2008,2013)$ and considering the IN effect, depending not only on temperature and ice supersaturation but also on the chemistry and surface area of multiple species of IN aerosols. The $\left[N_{\mathrm{a}}\right]$ enhancement generally suppresses the warm-rain process to reduce the rain water but provides more IN and supercooled CWC to accelerate the ice nucleation process. In addition, the rime-splintering mechanism also affects the ice particle profiles at the height with temperature ranging from -8 to $-3^{\circ} \mathrm{C}$ (Hallet and Mosssop, 1974). At the height of 6-8 km a.s.1. in Cu-TP and 4-6 km a.s.l. in Cu-NCP, the ice particle profiles are similar in the very low and low $\left[N_{\mathrm{a}}\right]$ cases, which is caused by the rime-splintering mechanism. The ice crystal production from the rime-splintering mechanism is related to the graupel particles and the cloud droplets with radii exceeding $24 \mu \mathrm{m}$. Large cloud droplets in the very low $\left[N_{\mathrm{a}}\right]$ facilitate the ice crystal productions from the rimesplintering mechanism, increasing the ice particle mass concentrations at the height of 6-8 kma.s.l. in $\mathrm{Cu}-\mathrm{TP}$ and 4$6 \mathrm{~km}$ a.s.l. in Cu-NCP. Furthermore, there are more ice particles in $\mathrm{Cu}-\mathrm{TP}$ than $\mathrm{Cu}-\mathrm{NCP}$ with the same $\left[N_{\mathrm{a}}\right]$ conditions. The initial formation time of ice crystals is advanced by at least $12 \mathrm{~min}$ in $\mathrm{Cu}$-TP compared to $\mathrm{Cu}-\mathrm{NCP}$ (Table 1). The $0{ }^{\circ} \mathrm{C}$ isotherm is at a level of around $5 \mathrm{~km}$ a.s.l. for the $\mathrm{Cu}-\mathrm{TP}$ and $\mathrm{Cu}-\mathrm{NCP}$. However, the occurrence heights for the $\mathrm{Cu}-$ $\mathrm{TP}$ and $\mathrm{Cu}-\mathrm{NCP}$ are more than $4 \mathrm{~km}$ and about $0.2 \mathrm{~km}$ a.s.l., respectively; when an air parcel perturbed in the boundary layer ascends to form a cloud, the rising distance to the $0^{\circ} \mathrm{C}$ isotherm is about $1 \mathrm{~km}$ over the TP and around $4 \mathrm{~km}$ over the NCP. Therefore, the ice crystal formation time is significantly shortened in the $\mathrm{Cu}$-TP compared to the $\mathrm{Cu}-\mathrm{NCP}$. The early formation of ice crystals not only facilitates their growth but also advances the glaciation process to intensify convections, further enhancing the growth process.

The rain water in $\mathrm{Cu}-\mathrm{TP}$ achieves the highest level in the very low $\left[N_{\mathrm{a}}\right]$ and lowest in the high $\left[N_{\mathrm{a}}\right]$, and vice versa in Cu-NCP (Fig. 4c and d). Not considering the contribution of graupel melting to the rain water, enhancement of $\left[N_{\mathrm{a}}\right]$ suppresses the warm-rain process to reduce the rain water but enhances the raindrop size, which conversely accelerates the raindrop falling (Table 1). In $\mathrm{Cu}$-TP, due to relatively low temperature below the freezing level and short falling distance (about $1 \mathrm{~km}$ ), graupel dominates the precipitating particles, melting less to rain water. So early occurrence of the warm-rain process in the very low $\left[N_{\mathrm{a}}\right]$ case causes the most rain water formation (Fig. 4c). However, in $\mathrm{Cu}-\mathrm{NCP}$, graupel falling below the freezing level tends to melt due to high temperature and long falling distance (about 4-5 km), enhancing the rain water formation. More ice particles and supercooled CWC in the high $\left[N_{\mathrm{a}}\right]$ case are favorable for the ice growth through deposition, aggregation among ice crystals, and riming of supercooled droplets (Wang and Change, 1993a, b; Lou et al., 2003), and heavily rimed ice crystals are transferred to graupel, enhancing the graupel formation. Therefore, in $\mathrm{Cu}-\mathrm{NCP}$, the high $\left[N_{\mathrm{a}}\right]$ corresponds to the maximum graupel content and also rain water content (Fig. $4 \mathrm{~d}$ and $\mathrm{h}$ ). However, in $\mathrm{Cu}-\mathrm{TP}$, below $12 \mathrm{~km}$, the low $\left[N_{\mathrm{a}}\right]$ cor- 
Table 1. Response of cloud properties in $\mathrm{Cu}-\mathrm{TP}$ and $\mathrm{Cu}-\mathrm{NCP}$ under three aerosol conditions*.

\begin{tabular}{|c|c|c|c|c|c|c|}
\hline \multirow[t]{2}{*}{ Clouds } & \multicolumn{3}{|c|}{$\mathrm{Cu}-\mathrm{TP}$} & \multicolumn{3}{|c|}{$\mathrm{Cu}-\mathrm{NCP}$} \\
\hline & Background & Clean & Polluted & Background & Clean & Polluted \\
\hline \multicolumn{7}{|c|}{ Initial formation time of hydrometeors (min) } \\
\hline Rain & 10 & 14 & 20 & 8 & 10 & 14 \\
\hline Ice crystal & 12 & 10 & 8 & 24 & 24 & 26 \\
\hline Graupel & 12 & 14 & 16 & 18 & 18 & 16 \\
\hline \multicolumn{7}{|c|}{$P$ mean of effective radius of hydrometeors $(\mu \mathrm{m})$} \\
\hline Rain & 119 & 132 & 647 & 110 & 151 & 223 \\
\hline Graupel & 559 & 665 & 917 & 221 & 303 & 447 \\
\hline
\end{tabular}

responds to the largest amounts of graupel. Early occurrence of the glaciation process in $\mathrm{Cu}$-TP causes most raindrops to be frozen to form graupel. The freezing rate of raindrops depends on the temperature, the raindrop size and number, and their corresponding variations with time (Lou et al., 2003). Generally, the raindrops with the larger size are easier to be frozen under the lower temperature. The $\left[N_{\mathrm{a}}\right]$ enhancement decreases the raindrop number but increases its size and updraft to lower the temperature, causing the maximum raindrop freezing efficiency under the low- $\left[N_{\mathrm{a}}\right]$ conditions. In addition, increasing the $\left[N_{\mathrm{a}}\right]$ invigorates the convection and produce larger graupel, and then the melting of the graupel causes the formation of larger raindrops (Table 1).

It is worth noting that ice particles and graupel are transported above $12 \mathrm{~km}$ a.s.l. or even exceeding $16 \mathrm{~km}$ a.s.l. (near tropopause) in $\mathrm{Cu}-\mathrm{TP}$, showing intensified convection and also contributing to moistening the upper troposphere.

\subsection{Response of convective strength to changes in aerosol concentrations}

The $p$ mean of the updraft and downdraft in a core area is used to measure the convective strength of the simulated cumulus clouds, which is defined by the absolute vertical wind speed exceeding $1 \mathrm{~m} \mathrm{~s}^{-1}$ and total condensed water mixing ratio being more than $10^{-2} \mathrm{~g} \mathrm{~kg}^{-1}$ (Wang, 2005). When the $\left[N_{\mathrm{a}}\right]$ increases from 20 to $9000 \mathrm{~cm}^{-3}$, the $p$ mean of the core updraft increases from 2.0 to $4.3 \mathrm{~m} \mathrm{~s}^{-1}$ in $\mathrm{Cu}-\mathrm{TP}$ and from 1.5 to $2.7 \mathrm{~m} \mathrm{~s}^{-1}$ in $\mathrm{Cu}-\mathrm{NCP}$ (Fig. 5a). The enhancement of the core updraft with increasing $\left[N_{\mathrm{a}}\right]$ is caused by the suppression of the warm-rain process to induce the more efficient mixed-phase process, releasing more latent heat to intensify the convection. With the same $\left[N_{\mathrm{a}}\right]$, the $p$ mean of the core updraft is larger in $\mathrm{Cu}-\mathrm{TP}$ than in $\mathrm{Cu}-\mathrm{NCP}$, showing the significant impact of the early occurrence of the glaciation process on the cloud development.

In $\mathrm{Cu}$-TP, with the $\left[N_{\mathrm{a}}\right]$ increase, the $p$ mean of the downdraft increases when the $\left[N_{\mathrm{a}}\right]$ is less than $90 \mathrm{~cm}^{-3}$, but it be- comes insensitive to the changes in $\left[N_{\mathrm{a}}\right]$ when the $\left[N_{\mathrm{a}}\right]$ is between 90 and $1800 \mathrm{~cm}^{-3}$, and it commences to decrease when the $\left[N_{\mathrm{a}}\right]$ exceeds $1800 \mathrm{~cm}^{-3}$ (Fig. 5b). The complex nonlinear variation of the $p$ mean of the downdraft with the [ $N_{\mathrm{a}}$ ] reflects the change in the vertical distribution of ice particles and graupel caused by the enhancement of $\left[N_{\mathrm{a}}\right]$ in $\mathrm{Cu}$-TP. The enhancement of the convective strength with increasing $\left[N_{\mathrm{a}}\right]$ not only intensifies the convection to facilitate precipitation, producing more precipitable particles, but also transports more ice particles and graupel to the upper troposphere due to the specific topography and further suppresses the occurrence of the downdraft. However, the $p$ mean of the downdraft in $\mathrm{Cu}-\mathrm{NCP}$ increases steadily with $\left[N_{\mathrm{a}}\right]$. Such an increase in the core downdraft with $\left[N_{\mathrm{a}}\right]$ might be caused by the formation of a large mass loading of precipitable particles to reduce buoyancy and increase downdrafts. Interestingly, when the $\left[N_{\mathrm{a}}\right]$ is less than about $450 \mathrm{~cm}^{-3}$, the $p$ mean of downdraft in $\mathrm{Cu}-\mathrm{TP}$ is greater than that in $\mathrm{Cu}-\mathrm{NCP}$, but opposite when $\left[N_{\mathrm{a}}\right]$ exceeding $450 \mathrm{~cm}^{-3}$, indicating the influence of the early occurrence of the glaciation process due to the specific topography in $\mathrm{Cu}$-TP.

The maximum updraft, representing the largest local latent heat release, generally increases with $\left[N_{\mathrm{a}}\right]$ in $\mathrm{Cu}-\mathrm{TP}$ and $\mathrm{Cu}-\mathrm{NCP}$ (Fig. 6a). The maximum updraft in $\mathrm{Cu}$-TP is much higher than that in $\mathrm{Cu}-\mathrm{NCP}$ with the same $\left[N_{\mathrm{a}}\right]$. In $\mathrm{Cu}-\mathrm{TP}$, when the $\left[N_{\mathrm{a}}\right]$ exceeds $750 \mathrm{~cm}^{-3}$, the maximum updraft becomes insensitive to changes in the $\left[N_{\mathrm{a}}\right]$. In $\mathrm{Cu}-\mathrm{NCP}$, the maximum updraft is not very sensitive to changes in the $\left[N_{\mathrm{a}}\right]$ when the $\left[N_{\mathrm{a}}\right]$ exceeds $2400 \mathrm{~cm}^{-3}$. The maximum downdraft, or the largest drag speed, indicating the largest strength to inhibit the development of the convection, also increases generally with the $\left[N_{\mathrm{a}}\right]$ in $\mathrm{Cu}-\mathrm{TP}$ and $\mathrm{Cu}-\mathrm{NCP}$ (Fig. 6b), but $\mathrm{Cu}$-TP produces a more intensive maximum downdraft than $\mathrm{Cu}-\mathrm{NCP}$. 

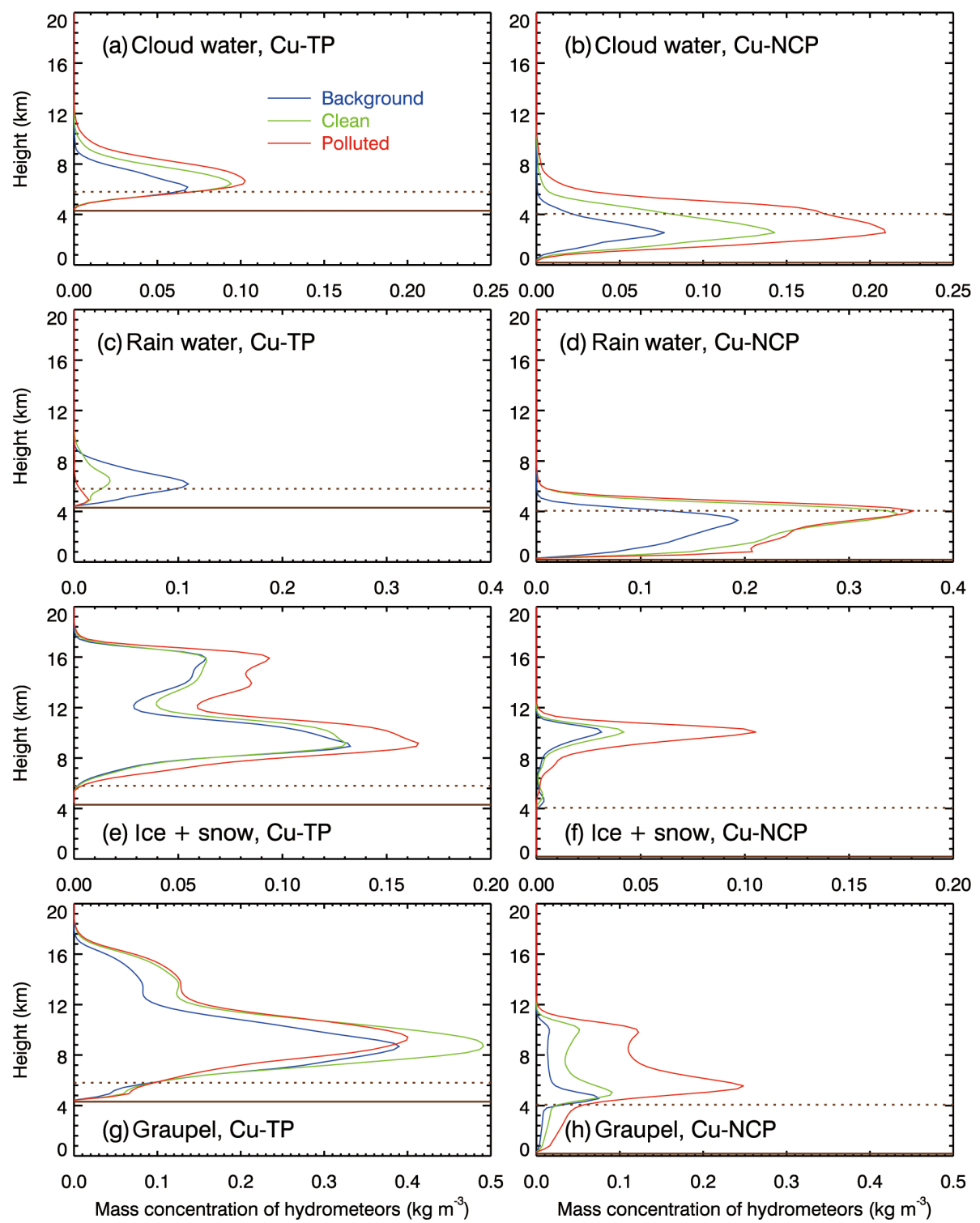

Figure 4. Vertical profiles of time-averaged masses of hydrometeors under background $\left(90 \mathrm{~cm}^{-3}\right.$, blue), clean $\left(900 \mathrm{~cm}^{-3}\right.$, green), and polluted $\left(9000 \mathrm{~cm}^{-3}\right.$, red) $\left[N_{\mathrm{a}}\right]$ conditions for $(\mathbf{a}, \mathbf{b})$ cloud water, $(\mathbf{c}, \mathbf{d})$ rain water, $(\mathbf{e}, \mathbf{f})$ ice particles (ice + snow), and $(\mathbf{g}, \mathbf{h})$ graupel in $\mathrm{Cu}-\mathrm{TP}$ and $\mathrm{Cu}-\mathrm{NCP}$, respectively. The brown solid and dotted lines represent the surface level and the $0{ }^{\circ} \mathrm{C}$ isotherm, respectively.

\subsection{Response of precipitation to changes in aerosol concentrations}

Figure 7 shows the variation of the accumulated precipitation with $\left[N_{\mathrm{a}}\right]$ in $\mathrm{Cu}-\mathrm{TP}$ and $\mathrm{Cu}-\mathrm{NCP}$. Generally, the precipitation increases with $\left[N_{\mathrm{a}}\right]$, which is consistent with previous modeling studies (e.g., Khain et al., 2005, 2008; Fan et al., 2007a; Li et al., 2008a, 2009). Since Cu-TP and Cu-NCP occur under humid conditions, the precipitation enhancement with $\left[N_{\mathrm{a}}\right]$ is also in good agreement with measurements. Observations have shown the precipitation enhancement around heavily polluted coastal urban areas (Shepherd and Burian, 2003; Ohashi and kida, 2002) or over oceans influenced by pollution aerosols (Cerveny and Balling Jr., 1998; Li et al., 2008b; Koren et al., 2012, 2014).

When the $\left[N_{\mathrm{a}}\right]$ is increased from about 20 to $9000 \mathrm{~cm}^{-3}$, the precipitation of $\mathrm{Cu}$-TP increases from 0.13 to $0.23 \mathrm{~mm}$; when the $\left[N_{\mathrm{a}}\right]$ exceeds $300 \mathrm{~cm}^{-3}$, the precipitation becomes insensitive to the variation in $\left[N_{\mathrm{a}}\right]$. In contrast, the precipitation of $\mathrm{Cu}-\mathrm{NCP}$ consistently increases from 0.03 to $0.37 \mathrm{~mm}$, with $\left[N_{\mathrm{a}}\right]$ ranging from 20 to $9000 \mathrm{~cm}^{-3}$. In addition, when the $\left[N_{\mathrm{a}}\right]$ is less than $500 \mathrm{~cm}^{-3}, \mathrm{Cu}-\mathrm{TP}$ produces more precipitation than $\mathrm{Cu}-\mathrm{NCP}$, which can be explained by the early occurrence of the glaciation process causing less warm rain but more efficient mixed-phase processes. However, when the $\left[N_{\mathrm{a}}\right]$ exceeds $500 \mathrm{~cm}^{-3}$, the precipitation efficiency of 

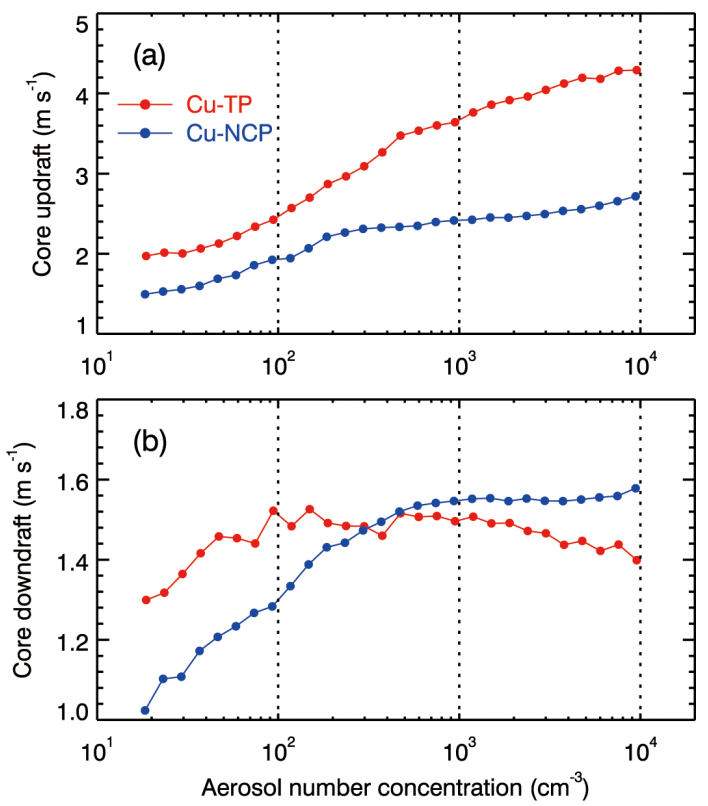

Figure 5. Simulated $p$ mean of (a) updraft and (b) downdraft in the core area (defined as an area where the absolute vertical velocity of wind is greater than $1 \mathrm{~m} \mathrm{~s}^{-1}$ and the total condensed water content exceeds $10^{-2} \mathrm{~g} \mathrm{~kg}^{-1}$ ) as a function of the initial $\left[N_{\mathrm{a}}\right]$ in $\mathrm{Cu}-\mathrm{TP}$ and $\mathrm{Cu}-\mathrm{NCP}$.
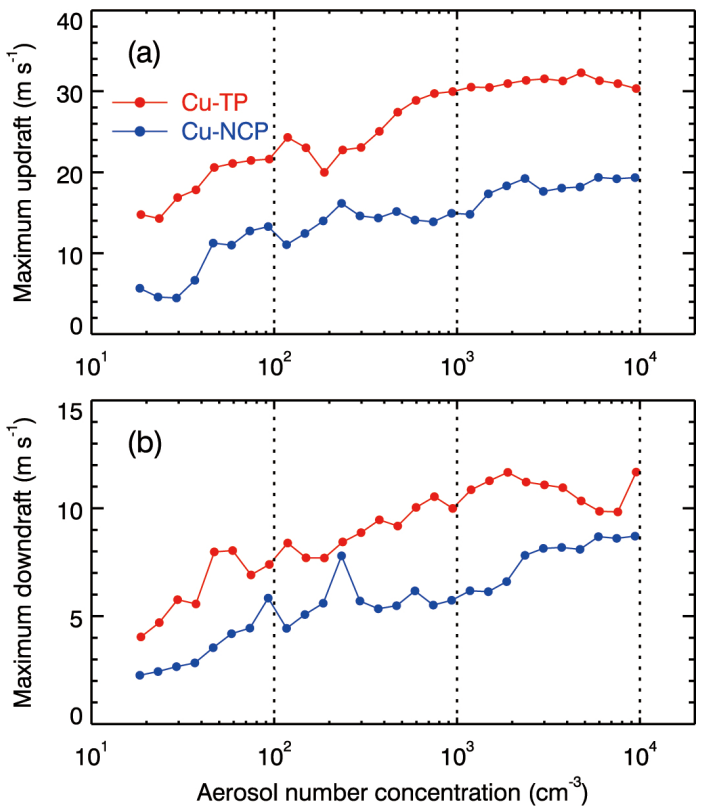

Figure 6. Modeled (a) maximum updraft and (b) minimum downdraft as a function of the initial $\left[N_{\mathrm{a}}\right]$ in $\mathrm{Cu}-\mathrm{TP}$ and $\mathrm{Cu}-\mathrm{NCP}$.

$\mathrm{Cu}-\mathrm{NCP}$ is higher than that of $\mathrm{Cu}-\mathrm{TP}$, although the convective strength is larger in $\mathrm{Cu}-\mathrm{TP}$ than $\mathrm{Cu}-\mathrm{NCP}$. The increasing convective strength with $\left[N_{\mathrm{a}}\right]$ not only enhances the precipitation but also transports more ice and graupel particles above $12 \mathrm{~km}$ to form the anvil. The ice particles and grau-

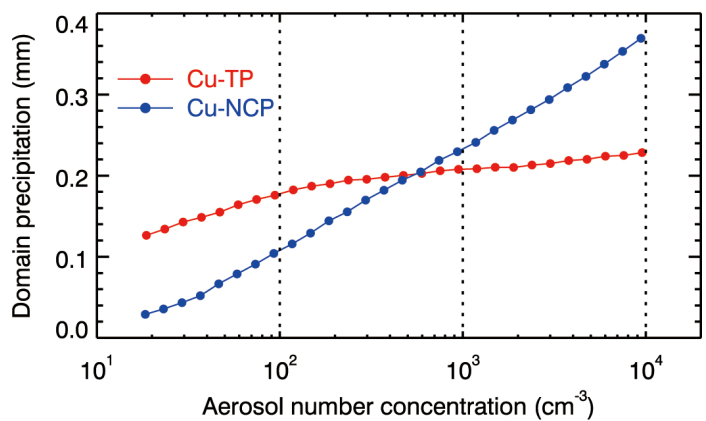

Figure 7. Modeled cumulative precipitation inside the model domain $(\mathrm{mm})$ as a function of the initial $\left[N_{\mathrm{a}}\right]$ in $\mathrm{Cu}-\mathrm{TP}$ and $\mathrm{Cu}-\mathrm{NCP}$.
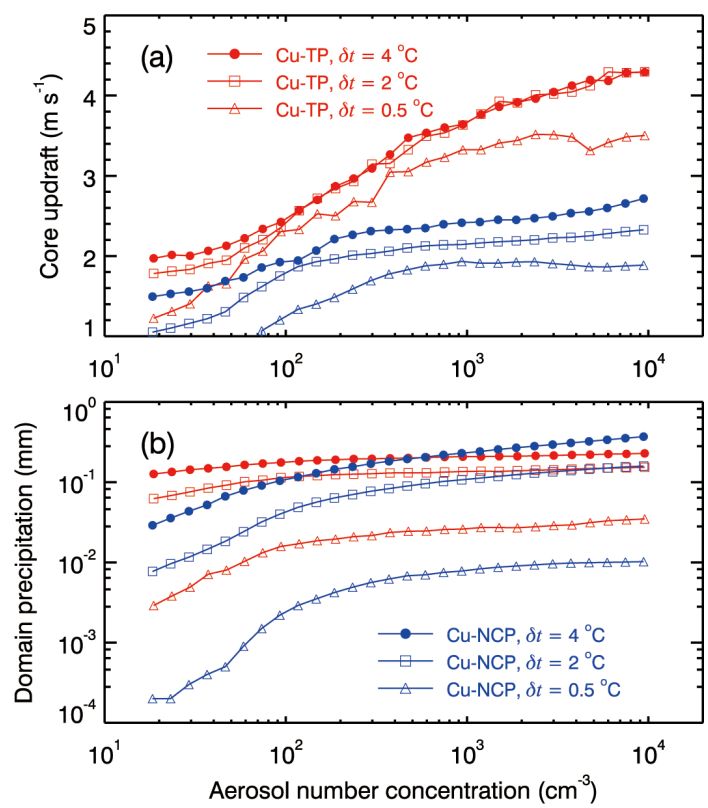

Figure 8. Response of (a) the $p$ mean of core updraft and (b) cumulative precipitation inside the model domain to the change in the maximum perturbation temperature of the warm bubble under various aerosol conditions in $\mathrm{Cu}-\mathrm{TP}$ and $\mathrm{Cu}-\mathrm{NCP}$.

pel in the anvil are subject to sublimation and evaporation to moisten the upper troposphere, and they decrease the precipitation efficiency in $\mathrm{Cu}-\mathrm{TP}$.

The water content and precipitation in the $\mathrm{Cu}-\mathrm{TP}$ respond well monotonically to the changes in the $\left[N_{\mathrm{a}}\right]$. Numerous studies have shown the reduced liquid water path (LWP) by increasing aerosols under relatively dry conditions (e.g., Khain et al., 2005). During the summer monsoon season, the atmosphere over the TP is humid due to the water vapor transport by the monsoon (Fig. 1a). The ambient humidity in the simulations of the $\mathrm{Cu}$-TP exceeds $80 \%$ in the low-level atmosphere, causing the good monotonicity in the responses of water content and precipitation to aerosols. 


\subsection{Sensitivity studies}

Recent studies have demonstrated that convection is more active and stronger during summertime over the Tibetan Plateau due to its unique thermodynamic forcing ( $\mathrm{Hu}$ et al., 2016). We have further performed sensitivity studies to explore the impact of the maximum perturbation temperature (MPT) in the warm bubble on the development of cumulus clouds. The MPTs of 2.0 and $0.5^{\circ} \mathrm{C}$ are used to trigger $\mathrm{Cu}-\mathrm{TP}$ and $\mathrm{Cu}-\mathrm{NCP}$, with the $\left[N_{\mathrm{a}}\right]$ ranging from 20 to $9000 \mathrm{~cm}^{-3}$.

For $\mathrm{Cu}-\mathrm{TP}$, the core updraft decreases slightly when the MPT is reduced from 4.0 to $2.0^{\circ} \mathrm{C}$, and particularly when the $\left[N_{\mathrm{a}}\right.$ ] exceeds $100 \mathrm{~cm}^{-3}$ the decrease of the core updraft is indiscernible (Fig. 8a). When the MPT is reduced from 2.0 to $0.5^{\circ} \mathrm{C}$, the core updraft decreases considerably. However, for $\mathrm{Cu}-\mathrm{NCP}$, the core updraft decreases substantially when the MPT is reduced from 4.0 to $0.5^{\circ} \mathrm{C}$. When the MPT is $0.5^{\circ} \mathrm{C}$ and the $\left[N_{\mathrm{a}}\right]$ is less than $80 \mathrm{~cm}^{-3}$, the updraft core area is not formed in $\mathrm{Cu}-\mathrm{NCP}$. When the MPT is the same, the core updraft is much larger in $\mathrm{Cu}-\mathrm{TP}$ than $\mathrm{Cu}-\mathrm{NCP}$ with the same $\left[N_{\mathrm{a}}\right]$; even the core updraft in $\mathrm{Cu}-\mathrm{TP}$ with a MPT of $0.5^{\circ} \mathrm{C}$ is larger than that in $\mathrm{Cu}-\mathrm{NCP}$ with a MPT of $4.0^{\circ} \mathrm{C}$ when the $\left[N_{\mathrm{a}}\right]$ is more than $80 \mathrm{~cm}^{-3}$. Therefore, under the unstable conditions over the Tibetan Plateau, a small perturbation can induce strong convections, which is primarily caused by early occurrence of the glaciation process due to the specific topography, as discussed in Sect. 3.1.

The accumulated precipitation generally decreases with the MPT in $\mathrm{Cu}-\mathrm{TP}$ and $\mathrm{Cu}-\mathrm{NCP}$ with the same $\left[N_{\mathrm{a}}\right]$ (Fig. 8b). When the MPT is $4.0^{\circ} \mathrm{C}, \mathrm{Cu}-\mathrm{NCP}$ produces more precipitation than $\mathrm{Cu}-\mathrm{TP}$, with the $\left[N_{\mathrm{a}}\right]$ exceeding $500 \mathrm{~cm}^{-3}$, but $\mathrm{Cu}$ $\mathrm{TP}$ produces much more precipitation than $\mathrm{Cu}-\mathrm{NCP}$, with a MPT of $0.5^{\circ} \mathrm{C}$ under all aerosol conditions. In addition, the precipitation generally increases with increasing $\left[N_{\mathrm{a}}\right]$ in $\mathrm{Cu}-$ $\mathrm{TP}$ and $\mathrm{Cu}-\mathrm{NCP}$ with various MPTs, and it does not exhibit a nonlinear variation with the $\left[N_{\mathrm{a}}\right]$, which is not consistent with the results in $\mathrm{Li}$ et al. (2008a). The possible reason is that in this study the maximum $p$ mean of CDNC is about $410 \mathrm{~cm}^{-3}$, which is much less than that in Li et al. (2008a). If the $\left[N_{\mathrm{a}}\right]$ is further increased, the precipitation might be suppressed.

\section{Summary and conclusions}

The aerosol-cloud interaction over the TP has been examined using the CR-WRF model with a two-moment microphysical scheme considering the aerosol effects on $\mathrm{CCN}$ and IN. For comparisons, two types of cumulus clouds, occurring over the TP and NCP in August 2014, are modeled to examine the response of the cumulus cloud development to the change in aerosol concentrations. A set of 28 aerosol profiles is utilized in simulations, with the surface aerosol number concentration varying from 20 to $9000 \mathrm{~cm}^{-3}$ and the sulfate mass concentration varying from 0.02 to $9.0 \mu \mathrm{g} \mathrm{cm}^{-3}$. Multiple aerosol species are considered to provide $\mathrm{CCN}$ and IN, including sulfate, nitrate, ammonium, organic and black carbon, and dust-like aerosols.

In general, with varying aerosol concentrations from very clean background conditions to polluted conditions, more aerosols are activated, significantly increasing the CDNC and decreasing the droplet size in $\mathrm{Cu}-\mathrm{TP}$ and $\mathrm{Cu}-\mathrm{NCP}$. Formation of a large amount of cloud droplets with small sizes suppresses the warm-rain process and enhances water vapor condensation efficiency and updraft to generate more available condensable water vapor. When more cloud droplets are transported above the $0^{\circ} \mathrm{C}$ isotherm, occurrence of the mixed-phase process releases more latent heat to further enhance the cloud core updraft and increase precipitation, intensifying the convections in $\mathrm{Cu}-\mathrm{TP}$ and $\mathrm{Cu}-\mathrm{NCP}$.

However, early occurrence of the glaciation process in $\mathrm{Cu}$ $\mathrm{TP}$, which is triggered at an elevation of more than $4000 \mathrm{~m}$, causes large differences between $\mathrm{Cu}-\mathrm{TP}$ and $\mathrm{Cu}-\mathrm{NCP}$. Many more supercooled cloud droplets are formed in $\mathrm{Cu}-\mathrm{TP}$ than $\mathrm{Cu}-\mathrm{NCP}$ with the same aerosol concentration, facilitating the mixed-phase process and significantly enhancing the core updraft and maximum updraft in $\mathrm{Cu}$-TP compared to $\mathrm{Cu}$ NCP. Nevertheless, the intensified convection induced by the increase of aerosol concentrations in $\mathrm{Cu}-\mathrm{TP}$ not only facilitates the precipitation but also delivers more ice-phase hydrometeors into the upper troposphere to form the anvil, decreasing the precipitation efficiency. Therefore, in $\mathrm{Cu}$ $\mathrm{TP}$, when aerosol concentrations are high, the precipitation enhancement becomes insignificant with increasing aerosol concentrations, but a considerable amount of ice-phase hydrometeors are lofted above $12 \mathrm{~km}$ or even exceeding $16 \mathrm{~km}$. Additionally, sensitivity studies have also shown that under the unstable conditions over the TP a small perturbation in temperature can induce strong convections, which is primarily caused by early occurrence of the glaciation process due to the specific topography.

In the present study, both $\mathrm{CCN}$ and IN effects are considered in the cloud simulations. However, there are still difficulties in quantitatively distinguishing those two effects on the ice-phase cloud development using sensitivity studies. Obviously, the CCN play a dominant role in the mixed-phase cloud development. Even when the IN are scare in the atmosphere, the mixed-phase cloud development is not hindered with sufficient CCN, because freezing of raindrops, the subsequent splinter-riming process, and homogeneous freezing of cloud droplets still initialize the glaciation process to facilitate the development of the mixed-phase cloud.

It is worth noting that, although the CAPE is similar for the $\mathrm{Cu}-\mathrm{TP}$ and $\mathrm{Cu}-\mathrm{NCP}$, it might not be fair to compare aerosol impacts on the cloud development over the TP with the NCP, considering the difference of the water vapor profile, wind shear, topography, and anthropogenic and natural aerosol sources between the two regions. However, the com- 
parisons have highlighted that the topography plays a large role in the development of cumulus over the TP.

Rapid growth of industrialization, urbanization, and transportation in Asia has caused severe air pollution, progressively increasing aerosol concentrations in the regions surrounding the TP. Pollution aerosols from surrounding areas have been observed to be transported to the TP. Considering the very clean atmosphere over the TP, elevated aerosol concentrations can considerably enhance the convections due to its specific topography. Numerous studies have shown that the TP significantly influences the formation and variability of the Asian summer monsoon through mechanical and thermal dynamical effects (e.g., Wu et al., 2007). In addition, Fu et al. (2006) have reported that convection over the TP provides the main pathway for cross-tropopause transport in the Asian monsoon/TP region. Hence, intensification of convections due to the increase of aerosol concentrations over the TP not only enhances the latent heat release to warm the middle troposphere, influencing the Asian summer monsoon, but also delivers more hydrometeors into the upper troposphere, allowing more water vapor to travel into the lower stratosphere. Further studies are needed to evaluate the aerosol indirect effect on the Asian summer monsoon and the troposphere-stratosphere exchange over the TP.

Data availability. Data used in the present study can be provided by Guohui Li (ligh@ieecas.cn).

Competing interests. The authors declare that they have no conflict of interest.

Acknowledgements. This work was supported by the National Natural Science Foundation of China (no. 41275153) and by the "Hundred Talents Program" of the Chinese Academy of Sciences. Naifang Bei is supported by the National Natural Science Foundation of China (no. 41275101). Luisa Molina and Wenfang Lei acknowledge support from US NSF award 1560494.

Edited by: R. Zhang

Reviewed by: two anonymous referees

\section{References}

Albrecht, B. A.: Aerosols, cloud microphysics and fractional cloudiness, Science, 245, 1227-1230, 1989.

Andreae, M. O., Rosenfeld, D., Artaxo, P., Costa, A. A., Frank, G. P., Longo, K. M., and Silva-Dias, M. A. F.: Smoking rain clouds over the Amazon, Science, 303, 1337-1342, 2004.

Binkowski, F. S. and Roselle, S. J.: Models-3 Community Multiscale Air Quality (CMAQ) model aerosol component 1. Model description, J. Geophys. Res., 108, 4183, https://doi.org/10.1029/2001JD001409, 2003.
Cerveny, R. S. and Bailing Jr., R. C.: Weekly cycles of air pollutants, precipitation and tropical cyclones in the coastal NW Atlantic region, Nature, 394, 561-563, 1998.

Dagan, G., Koren, I., and Altaratz, O.: Aerosol effects on the timing of warm rain processes, Geophys. Res. Lett., 42, 4590-4598, https://doi.org/10.1002/2015GL063839, 2015.

Decesari, S., Facchini, M. C., Carbone, C., Giulianelli, L., Rinaldi, M., Finessi, E., Fuzzi, S., Marinoni, A., Cristofanelli, P., Duchi, R., Bonasoni, P., Vuillermoz, E., Cozic, J., Jaffrezo, J. L., and Laj, P.: Chemical composition of $\mathrm{PM}_{10}$ and $\mathrm{PM}_{1}$ at the high-altitude Himalayan station Nepal Climate ObservatoryPyramid (NCO-P) (5079 ma.s.1.), Atmos. Chem. Phys., 10, 4583-4596, https://doi.org/10.5194/acp-10-4583-2010, 2010.

DeMott, P. J., Meyers, M. P., and Cotton, W. R.: Parameterization and impact of ice initiation processes relevant to numerical model simulations of cirrus clouds, J. Atmos. Sci., 51, 77-90, https://doi.org/10.1175/15200469(1994)051<0077:paioii>2.0.co;2, 1994.

D’Errico, M., Cagnazzo, C., Gogli, P. G., Lau, K. M., Von, H. J., Fierli, F., and Cherchi, A.: Indian monsoon and the elevated-heat pump mechanism in a coupled aerosol-climate model, J. Geophys. Res., 120, 8712-8723, https://doi.org/10.1002/2015JD023346, 2015.

Engling, G., Zhang, Y.-N., Chan, C.-Y., Sang, X.-F., Lin, M., Ho, K.-F., Li, Y.-S., Lin, C.-Y., and Lee, J. J.: Characterization and sources of aerosol particles over the southeastern Tibetan Plateau during the Southeast Asia biomass-burning season, Tellus B, 63, 117-128, https://doi.org/10.1111/j.1600-0889.2010.00512.x, 2011.

Fan, J., Zhang, R., Li, G., Tao, W.-K., and Li, X.: Simulations of cumulus clouds using a spectral microphysics cloud-resolving model, J. Geophys. Res., 112, D04201, https://doi.org/10.1029/2006JD007688, 2007a.

Fan, J., Zhang, R., Li, G., and Tao, W.-K.: Effects of aerosols and relative humidity on cumulus clouds, J. Geophys. Res., 112, D14204, https://doi.org/10.1029/2006JD008136, 2007b.

Fan, J., Yuan, T. L., Comstock, J. M., Ghan, S., Khain, A., Leung, L. R., Li, Z. Q., Martins, V. J., and Ovchinnikov, M.: Dominant role by vertical wind shear in regulating aerosol effects on deep convective clouds, J. Geophys. Res., 114, D22206, https://doi.org/10.1029/2009jd012352, 2009.

Fan, J., Leung, L. R., Rosenfeld, D., Chen, Q., Li, Z. Q., Zhang, J. Q., and Yan, H. R.: Microphysical effects determine macrophysical response for aerosol impacts on deep convective clouds, P. Natl. Acad. Sci. USA, 110, E4581-E4590, https://doi.org/10.1073/pnas.1316830110, 2013.

Fan, J., Wang, Y., Rosenfeld, D., and Liu, X.: Review of aerosolcloud interactions: Mechanisms, significance, and challenges, J. Atmos. Sci., 73, 4221-4252, 2016.

Fu, R., Hu, Y., Wright, J. S., Jiang, J. H., Dickinson, R. E., Chen, M., Filipiak, M., Read, W. G., Waters, J. W., and $\mathrm{Wu}, \mathrm{D}$. L.: Short circuit of water vapor and polluted air to the global stratosphere by convective transport over the Tibetan Plateau, P. Natl. Acad. Sci. USA, 103, 5664-5669, https://doi.org/10.1073/pnas.0601584103, 2006.

Hallett, J. and Mossop, S. C.: Production of secondary ice crystals during the riming process, Nature, 249, 26-28, 1974.

Houghton, J.: The science of global warming, Interdiscip. Sci. Rev., 26, 247-257, https://doi.org/10.1179/030801801679485, 2001. 
Hu, L., Deng, D., Gao, S., and Xu, X.: The seasonal variation of Tibetan Convective Systems: Satellite observation, J. Geophys. Res., 121, 5512-5525, https://doi.org/10.1002/2015JD024390, 2016.

IPCC: Summary for Policymakers, in: Climate Change 2013: The Physical Science Basis. Contribution of Working Group I to the Fifth Assessment Report of the Intergovernmental Panel on Climate Change, edited by: Stocker, T. F., Qin, D., Plattner, G.-K., Tignor, M., Allen, S. K., Boschung, J., Nauels, A., Xia, Y., Bex, V., and Midgley, P. M., Cambridge University Press, Cambridge, UK and New York, NY, USA, 2013.

Jacobson, M. Z.: Analysis of aerosol interactions with numerical techniques for solving coagulation, nucleation, condensation, dissolution, and reversible chemistry among multiple size distributions, J. Geophys. Res., 107, 4366, https://doi.org/10.1029/2001JD002044, 2002.

Kaufman, Y. J. and Nakajima, T.: Effect of Amazon smoke on cloud microphysics and albedo - Analysis from satellite imagery, J. Appl. Meteorol., 32, 729-744, 1993.

Kaufman, Y. J., Koren, I., Remer, L. A., Rosenfeld, D., and Rudich, Y.: The effect of smoke, dust, and pollution aerosol on shallow cloud development over the Atlantic Ocean, P. Natl. Acad. Sci. USA, 102, 11207-11212, https://doi.org/10.1073/pnas.0505191102, 2005.

Khain, A. P.: Notes on state-of-art investigations of aerosol effects on precipitation: a critical review, Environ. Res. Lett., 4, 015004, https://doi.org/10.1088/1748-9326/4/1/015004, 2000.

Khain, A. P., Rosenfeld, D., and Pokrovsky, A.: Aerosol impact on the dynamics and microphysics of deep convective clouds, Q. J. Roy. Meteorol. Soc., 131, 2639-2663, https://doi.org/10.1256/Qj.04.62, 2005.

Khain, A. P., BenMoshe, N., and Pokrovsky, A.: Factors determining the impact of aerosols on surface precipitation from clouds: An attempt at classification, J. Atmos. Sci., 65, 1721-1748, https://doi.org/10.1175/2007jas2515.1, 2008.

Koren, I., Remer, L. A., Altaratz, O., Martins, J. V., and Davidi, A.: Aerosol-induced changes of convective cloud anvils produce strong climate warming, Atmos. Chem. Phys., 10, 5001-5010, https://doi.org/10.5194/acp-10-5001-2010, 2010.

Koren, I., Altaratz, O., Remer, L. A., Feingold, G., Martins, J. V., and Heiblum, R. H.: Aerosol-induced intensification of rain from the tropics to the mid-latitudes, Nat. Geosci., 5, 118-122, https://doi.org/10.1038/NGEO1364, 2012.

Koren, I., Dagan, G., and Altaratz, O.: From aerosol-limited to invigoration of warm convective clouds, Science, 344, 1143-1146, https://doi.org/10.1126/science.1252595, 2014.

Lau, K.-M., Tsay, S. C., Hsu, C., Chin, M., Ramanathan, V., Wu, G.-X., Li, Z., Sikka, R., Holben, B., Lu, D., Chen, H., Tartari, G., Koudelova, P., Ma, Y., Huang, J., Taniguchi, K., and Zhang, R.: The joint aerosol-monsoon experiment: A new challenge for Monsoon Climate Research, B. Am. Meteorol. Soc., 89, 369383, 2008

Lee, S. S., Donner, L. J., Phillips, V. T. J., and Ming, Y.: The dependence of aerosol effects on clouds and precipitation on cloudsystem organization, shear and stability, J. Geophys. Res., 113, D16202, https://doi.org/10.1029/2007jd009224, 2008.

Levin, Z. and Cotton, W.: Aerosol pollution impact on precipitation: A scientific review, World Meteorological Organization, Geneva, Switzerland, 2007.
Li, G., Wang, Y., and Zhang, R. Y.: Implementation of a two- moment bulk microphysics scheme to the WRF model to investigate aerosol-cloud interaction, J. Geophys. Res., 113, D15211, https://doi.org/10.1029/2007jd009361, 2008a.

Li, G., Wang, Y., Lee, K.-H., Diao, Y., and Zhang, R.: Increased winter precipitation over the North Pacific from 19841994 to 1995-2005 inferred from the Global Precipitation Climatology Project, Geophys. Res. Lett., 35, L13821, https://doi.org/10.1029/2008GL034668, 2008b.

Li, G., Wang, Y., Lee, K.-H., Diao, Y., and Zhang, R.: Impacts of aerosols on the development and precipitation of a mesoscale squall line, J. Geophys. Res., 114, D17205, https://doi.org/10.1029/2008JD011581, 2009.

Li, X., Tao, W.-K., Masunaga, H., Gu, G., and Zeng, X.: Aerosol effects on cumulus congestus population over the tropical Pacific: Cloud resolving modeling study, J. Meteorol. Soc. Jpn., 91, 817833, 2013.

Li, Z., Lau, W. K.-M., Ramanathan, V., Wu, G., Ding, Y., Manoj, M. G, Liu, J., Qian, Y., Li, J., Zhou, T, Fan, J., Rosenfeld, D, Ming, Y, Wang, Y., Huang, J, Wang, B., Xu, X., Lee, S.-S. Cribb, M., Zhang, F., Yang, X., Zhao, C., Takemura, T., Wang, K., Xia, X., Yin, Y., Zhang, H, Guo, J., Zhai, P. M. Zhai, Sugimoto, N., Babu, S. S., and Brasseur, G. P.: Aerosol and monsoon climate interactions over Asia, Rev. Geophys., 54, 866-929, 2016.

Lin, Y., Wang, Y., Pan, B., Hu, J., Liu, Y., and Zhang, R.: Distinct impacts of aerosols on an evolving continental cloud complex during the RACORO field campaign, J. Atmos. Sci., 73, 36813700, 2016.

Loftus, A. M. and Cotton, W. R.: Examination of CCN impacts on hail in a simulated supercell storm with triple-moment hail bulk microphysics, Atmos. Res., 147-148, 183-204, 2014.

Lou, X.-F., Hu, Z.-J., and Shi, Y.-Q.: Numerical simulation of a heavy rainfall case in South China, Adv. Atmos. Sci., 20, 128138, 2003.

McComiskey, A. and Feingold, G.: The scale problem in quantifying aerosol indirect effects, Atmos. Chem. Phys., 12, 1031-1049, https://doi.org/10.5194/acp-12-1031-2012, 2012.

Ohashi, Y. and Kida, H.: Local circulations developed in the vicinity of both coastal and inland urban areas: A numerical study with a mesoscale atmospheric model, J. Appl. Meteorol., 41, 30-45, 2002.

Penner, J. E., Hegg, D., and Leaitch, R.: Unraveling the role of aerosols in climate change, Environ. Sci. Technol., 35, 332-340, 2001.

Petters, M. D. and Kreidenweis, S. M.: A single parameter representation of hygroscopic growth and cloud condensation nucleus activity, Atmos. Chem. Phys., 7, 1961-1971, https://doi.org/10.5194/acp-7-1961-2007, 2007.

Petters, M. D. and Kreidenweis, S. M.: A single parameter representation of hygroscopic growth and cloud condensation nucleus activity - Part 2: Including solubility, Atmos. Chem. Phys., 8, 6273-6279, https://doi.org/10.5194/acp-8-6273-2008, 2008.

Petters, M. D. and Kreidenweis, S. M.: A single parameter representation of hygroscopic growth and cloud condensation nucleus activity - Part 3: Including surfactant partitioning, Atmos. Chem. Phys., 13, 1081-1091, https://doi.org/10.5194/acp13-1081-2013, 2013.

Phillips, T. J., DeMott, P. J., and Andronache, C.: An empirical parameterization of heterogeneous ice nucleation for multi- 
ple chemical species of aerosol, J. Atmos. Sci., 65, 2757-2783, 2008.

Phillips, T. J., DeMott, P. J., Andronache, C., Pratt, K. A., Prather, K. A., Subramanian, R., and Twohy, C.: Improvements to an empirical parameterization of heterogeneous ice nucleation and its comparison with observations, J. Atmos. Sci., 70, 378-408, 2013.

Pruppacher, H. R. and Klett, J. D.: Microphysics of clouds and precipitation, second revised and enlarged edition with an introduction to cloud chemistry and cloud electricity, Kluwer Academic Publishers, Reidel, Dordrecht, 954 pp., 1997.

Ramanathan. V., Crutzen, P. J., Kiehl, J. T., and Rosenfeld, D.: Aerosols, climate, and the hydrological cycle, Science, 294, 2119-2124, 2001.

Rogers, R. R. and Yau, M. K.: A short course in cloud physics, Pergamon, Tarrytown, New York, 1989.

Rosenfeld, D.: Suppression of rain and snow by urban and industrial air pollution, Science, 287, 1793-1796, 2000.

Rosenfeld, D. and Lensky, I. M.: Satellite-based insights into precipitation formation processes in continental and maritime convective clouds, B. Am. Meteorol. Soc., 79, 2457-2476, 1998.

Rosenfeld, D. and Woodley, W. L.: Deep convective clouds with sustained supercooled liquid water down to $-37.5^{\circ} \mathrm{C}$, Nature, 405, 440-442, 2000.

Rosenfeld, D., Lohmann, U., Raga, G. B., O’Dowd, C. D., Kulmala, M., Fuzzi, S., Reissell, A., and Andreae, M. O.: Flood or drought: how do aerosols affect precipitation?, Science, 321, 1309-1313, 2008.

Shepherd, J. M. and Burian, S. J.: Detection of urbaninduced rainfall anomalies in a major coastal city, Earth Interact., 7, 1-14, https://doi.org/10.1175/10873562(2003)007<0001:DOUIRA>2.0.CO;2, 2003.

Skamarock, W. C.: Evaluating mesoscale NWP models using kinetic energy spectra, Mon. Weather Rev., 132, 3019-3032, 2004.

Tao, W. K., Chen, J. P., Li, Z., Wang, C., and Zhang, C.: Impact of aerosols on convective clouds and precipitation, Rev. Geophys., 50, RG2001, 1-62, https://doi.org/10.1029/2011RG000369, 2012.

Twomey, S. A.: The influence of pollution on the shortwave albedo of clouds, J. Atmos. Sci., 34, 1149-1152, 1977.

Van Den Heever, S. C. and Cotton, W. R.: Urban aerosol impacts on downwind convective storms, J. Appl. Meteorol. Clim., 46, 828-850, https://doi.org/10.1175/JAM2492.1, 2007.

Wang, C.: A modeling study of the response of tropical deep convection to the increase of cloud condensation nuclei concentration, 1. Dynamics and microphysics, J. Geophys. Res., 110, D21211, https://doi.org/10.1029/2004JD005720, 2005.
Wang, C. and Chang, J.: Three-dimensional numerical model of cloud dynamics, microphysics, and chemistry 1 . Concepts and formulation, J. Geophys. Res., 98, 14827-14844, 1993a.

Wang, C. and Chang, J.: Three-dimensional numerical model of cloud dynamics, microphysics, and chemistry 2 . A case study of the dynamics and microphysics of a severe local storm, J. Geophys. Res., 98, 14845-14862, 1993 b.

Wang, Y., Wan, Q., Meng, W., Liao, F., Tan, H., and Zhang, R.: Long-term impacts of aerosols on precipitation and lightning over the Pearl River Delta megacity area in China, Atmos. Chem. Phys., 11, 12421-12436, https://doi.org/10.5194/acp-11-124212011, 2011.

Wang, Y., Khalizov, A., Levy, M., and Zhang, R.: New directions: Light absorbing aerosols and their atmospheric impacts", Atmos. Environ., 81, 713-715, 2013.

Wang, Y., Wang, M., Zhang, R., Ghan, S. J., Lin, Y., Hu, J., Pan, B., Levy, M., Jiang, J., and Molina, M. J.: Assessing the effects of anthropogenic aerosols on Pacific storm track using a multi-scale global climate mode, P. Natl Acad. Sci. USA, 111, 6894-6899, 2014a.

Wang, Y., Zhang, R., and Saravanan, R.: Asian pollution climatically modulates mid-latitude cyclones following hierarchical modelling and observational analysis, Nat. Commun., 5, 3098, https://doi.org/10.1038/ncomms4098, 2014b.

Wu, G., Liu, Y., Zhang, Q., Duan, A., Wang, T., Wan, R., Liu, X., Li, W., Wang, Z., and Liang, X.: The influence of mechanical and thermal forcing by the Tibetan Plateau on Asian climate, J. Hydrometeorol., 8, 770-789, https://doi.org/10.1175/JHM609.1, 2007.

Xu, B., Cao, J., Hansen, J., Yao, T., Joswia, D. R., Wang, N., Wu, G., Wang, M., Zhao, H., and Yang, W.: Black soot and the survival of Tibetan glaciers, P. Natl. Acad. Sci. USA, 106, 22114-22118, https://doi.org/10.1073/pnas.0910444106, 2009.

Yang, X., Ferrat, M., and Li, Z.: New evidence of orographic precipitation suppression by aerosols in central China, Meteorol. Atmos. Phys., 119, 17-29, https://doi.org/10.1007/s00703-0120221-9, 2013.

Zhang, R. Y., Li, G. H., Fan, J. W., Wu, D. L., and Molina, M. J.: Intensification of Pacific storm track linked to Asian pollution, P. Natl. Acad. Sci. USA, 104, 5295-5299, 2007. 